ISSN: 2224-0616

Int. J. Agril. Res. Innov. \& Tech. 3 (2): 41-48, December, 2013 Available online at http://www.ijarit.webs.com

\title{
SUITABILITY OF Chlorella ellipsoidea AS FOOD FOR PRODUCTION OF THE ROTIFER Brachionus calyciflorus
}

\author{
S. Akter ${ }^{1}$, M. Shahjahan ${ }^{*}$, M.S. Rahman ${ }^{1}$ and P.S. Das ${ }^{2}$ \\ Received 7 August 2013, Revised 10 December 2013, Accepted 25 December 2013, Published online 31 December 2013
}

\begin{abstract}
Rotifers are valuable live food for larval fish and crustacean in aquaculture. In the present study, we conducted an experiment to evaluate the suitability of Chlorella ellipsoidea as food for production of the rotifer, Brachionus calyciflorus. The experiment was carried out in three treatments using dried powder Chlorella ellipsoidea (T1), fresh live Chlorella ellipsoidea (T2) and Baker's yeast (T3) as food with three replications. For supplying food to rotifers, C. ellipsoidea was cultured sufficiently in different inexpensive culture media before rotifer culture and it was continued up to the end of the rotifer culture experiment. The ranges of environmental factors analyzed were suitable for both C. ellipsoidea and rotifers culture during the experimental period. Maximum cell densities of $C$. ellipsoidea were recorded in inexpensive pulse bran extract medium during the culture period. The mean population densities (means \pm SEM) of $B$. calyciflorus were significantly $(p<0.01)$ highest in

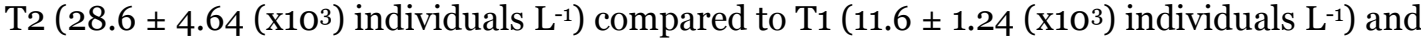
$\mathrm{T}_{3}\left(11.4 \pm 1.82\left({\left.\mathrm{x} 10^{3}\right)}^{3}\right)\right.$ individuals $\left.\mathrm{L}^{-1}\right)$. The findings of present study revealed that fresh cultured C. ellipsoidea was the best food for production of the rotifer, B. calyciflorus.
\end{abstract}

Keywords: Rotifer, Chlorella, Aquaculture, Culture Medium, Water Quality

${ }^{1}$ Department of Fisheries Management, Bangladesh Agricultural University, Mymensingh-2202, Bangladesh

${ }^{2}$ FAO-BOBLME-BFRI Hilsa Project, Bangladesh

*Corresponding author's email: mdshahjahan@bau.edu.bd (M. Shahjahan)

\section{Introduction}

Rotifers are multicellular animals with body cavities that are partially lined by mesoderm. These organisms are valuable live food for larval fish and crustacean culture. Several characteristics of rotifers, including their nutritional quality, body size and relatively slow motility have contributed to their usefulness as good prey for active larvae (Snell and Carrillo, 1984). In general, rotifers have both nutrient content and a high rate of daily production (Lubzens, 1987). Rotifer transmits adequate supplies of micro and macronutrients, vitamin and even antibodies to the fish larvae (Gatesoupe, 1982). The level of polyunsaturated $\omega-3$ fatty acid in rotifer is believed to affect both survival and growth rate of fish larvae (Koven et al., 1990). Rotifer forms an excellent initial food because of its appropriate size $(130-320 \mu \mathrm{m})$, planktonic nature, rapid production rate, suitability for mass culture under controlled conditions, ability to grow and reproduce in high density cultures and the possibility of artificially manipulating its nutritional qualities along with the euryhaline nature (Dhert et al., 2001). Among different species of rotifer, Brachionus has been widely used as essential food source in raising marine fish, shrimp and crab larvae due to its tolerance to the marine environment (Lubzens, 1987; Cheng et al., 2004). Several researchers in different countries of the world have been conducted researches on rotifer culture, enrichment of rotifer culture, development of rotifer culture methods for the purpose of fish larvae feeding for improvement of fish culture industry (Lubzens et al., 2001; Dhert et al., 2001; Hagiwara et al., 2001; Leschenko et al., 2005; Arimoro, 2007; Ludwig et al., 2008). On the other hand, very few studies regarding rotifers culture have been conducted in Bangladesh, although this country is potentially rich for aquaculture.

Rotifers have specialized organ systems and a complete digestive tract that includes both a mouth and anus. As rotifers are microscopic animals, their diet must consist of matter small enough to fit through their tiny mouths during filter feeding. Rotifers are primarily omnivorous, but some species have been known to be cannibalistic. The diet of rotifers most commonly consists of dead or decomposing organic materials, as well as unicellular algae and other phytoplankton that are primary producers in aquatic communities. Such feeding habits make some rotifers primary consumers. Rotifers are in 
turn prey to carnivorous secondary consumers, including shrimp and crabs. Brachionus feeds on microalgae, protozoa, bacteria and dead organic materials (Rezeq and James, 1987) in addition to artificial feeds. Diet is regarded as the most important criterion that could affect growth as well as nutritive quality of rotifers (Lubzens, 1987; Nhu, 2004).

Since large-scale algal production is relatively cheap, under field and laboratory conditions, various types of algae are routinely being produced for feeding planktonic rotifers (Groeneweg and Schluter, 1981). Chlorella is an excellent food for rotifer if supplemented with vitamin $\mathrm{B}_{12}$ (Hirayama et al., 1989) and some strain of Chlorella are known to absorb vitamin $\mathrm{B}_{12}$ from culture medium and store this vitamin in their cells (Maruyama and Hirayama, 1993). In the present study, we cultured Chlorella ellipsoidea in different media and used as food in powdered and fresh live form along with Backer's yeast in culture of the rotifer, Brachionus calyciflorus.

\section{Materials and Methods Experimental design}

The culture experiment of rotifer was conducted in a balcony of a room at $2^{\text {nd }}$ floor of the Fisheries Faculty Building of Bangladesh Agricultural University, facing the north on a steel shelf having 3 sides partially closed with a light coloured polyester cloth (Fig. 1). The experiment had three treatments with three replications i.e., treatment 1 (T1), in which the powdered dried Chlorella ellipsoidea was used as feed for rotifer, treatment 2 (T2), in which fresh cultured $C$. ellipsoidea were used as feed and treatment 3 (T3), in which baker's yeast was used as feed.

For supplying food to rotifers, the culture experiment of $C$ ellipsoidea was also conducted at the same place where there is sufficient sun light for their growth (Figure 1). This experiment had also three treatments with four replications i.e., treatment 1 ( $\mathrm{T} 1$ ), in which the expensive medium (inorganic), treatment 2 (T2), in which the inexpensive medium (pulse bran extract) and treatment 3 (T3), in which the inexpensive medium (soil extract) were used for $C$. ellipsoidea culture.

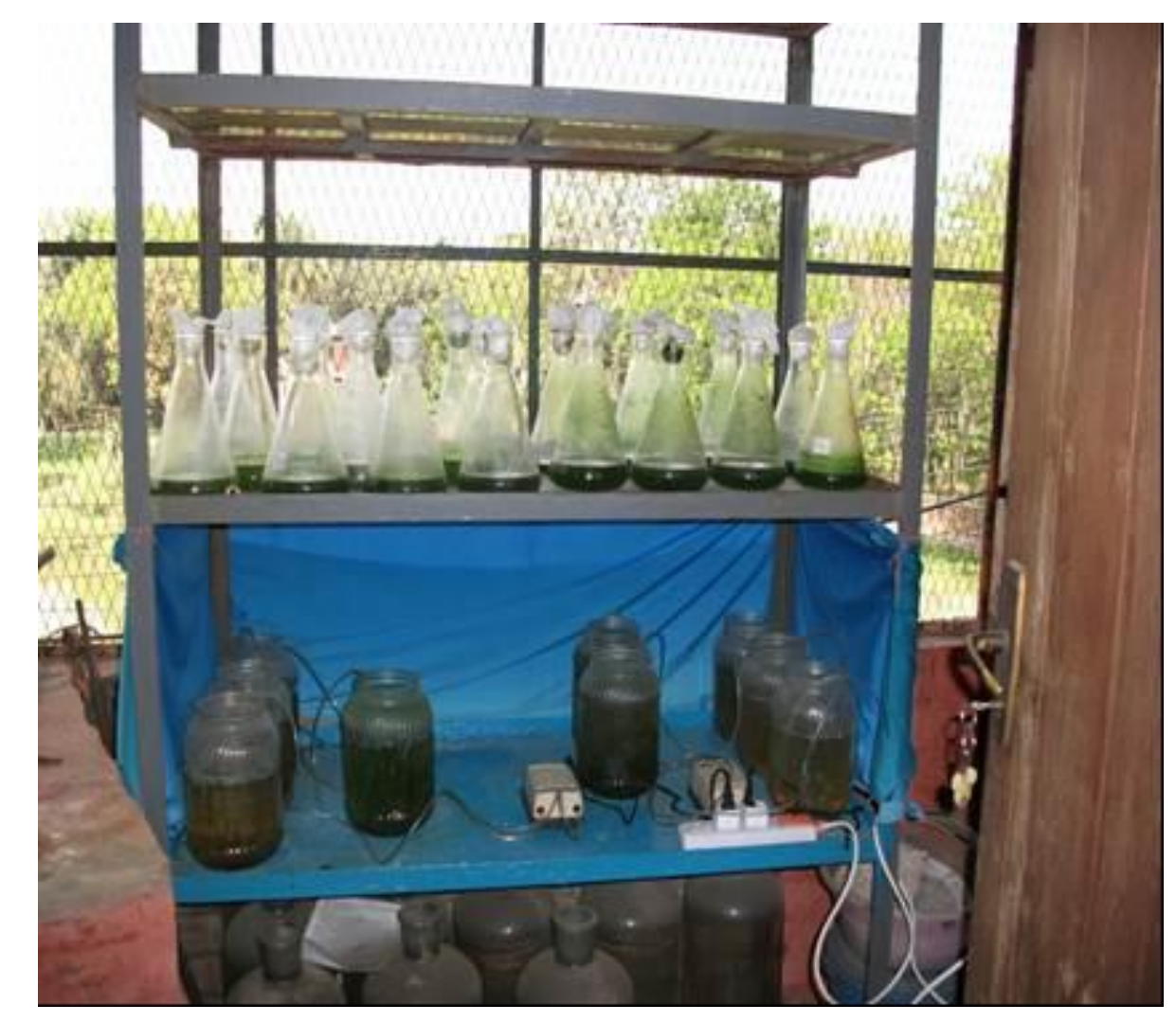

Fig. 1. Culture of Chlorella ellipsoidea and Brachionus calyciflorus on a steel shelf 


\section{Preparation of media for Chlorella ellipsoidea culture}

\section{Preparation of inorganic culture medium}

Inorganic medium was prepared with the inoculation of stock solutions of 8 major (macro) nutrients and 6 minor (micro or trace) nutrients. Ten litre distilled water was taken in a 30 litre plastic bucket and stock solutions were added and mixed well in the bucket and stored in a 15 litre plastic container. Stock solutions were prepared in distilled water using different chemical compounds as major nutrients and trace elements (Table 1 ).

Table 1. Composition of inorganic algal growth medium (modified GBII algal growth medium of Stainer et al., 1971)

\begin{tabular}{|c|c|c|c|}
\hline \multicolumn{2}{|c|}{ Ingredients (compounds) } & \multirow{2}{*}{ 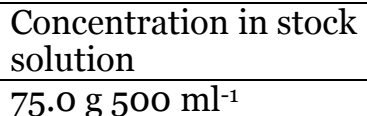 } & \multirow{2}{*}{$\begin{array}{l}\text { Inoculation in growth } \\
100{\mathrm{ml} 10 \mathrm{~L}^{-1}}^{-1}\end{array}$} \\
\hline Major nutrients & $\mathrm{NaNO}_{3}$ & & \\
\hline & $\mathrm{MgSO}_{4} \cdot 7 \mathrm{H}_{2} \mathrm{O}$ & 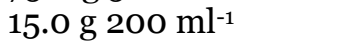 & $10 \mathrm{ml}^{10 \mathrm{~L}^{-1}}$ \\
\hline & $\mathrm{K}_{2} \mathrm{HPO}_{4}$ & 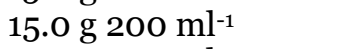 & $10 \mathrm{ml}^{10 \mathrm{~L}^{-1}}$ \\
\hline & $\mathrm{CaCl}_{2} \cdot 2 \mathrm{H}_{2} \mathrm{O}$ & 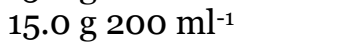 & $10 \mathrm{ml}^{10 \mathrm{~L}^{-1}}$ \\
\hline & $\mathrm{Na}_{2} \mathrm{CO}_{3}$ & 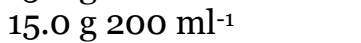 & $10 \mathrm{ml}^{10 \mathrm{~L}^{-1}}$ \\
\hline & EDTA & 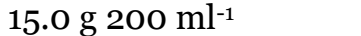 & $10 \mathrm{ml}_{10 \mathrm{~L}^{-1}}$ \\
\hline & Ferric ammonium citrate & 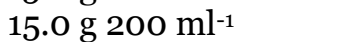 & $10 \mathrm{ml}_{10 \mathrm{~L}^{-1}}$ \\
\hline & Citric acid & 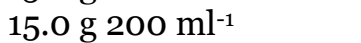 & 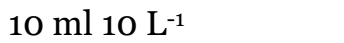 \\
\hline \multirow[t]{5}{*}{ Trace elements } & $\mathrm{MnCl}_{2} \cdot 4 \mathrm{H}_{2} \mathrm{O}$ & $1.810 \mathrm{~g} \mathrm{~L}^{-1}$ & $10{\mathrm{ml} 10 \mathrm{~L}^{-1}}^{-1}$ \\
\hline & $\mathrm{Na}_{2} \mathrm{MoO}_{4} \cdot \mathrm{H}_{2} \mathrm{O}$ & $0.390 \mathrm{~g} \mathrm{~L}^{-1}$ & $10 \mathrm{ml}^{10 \mathrm{~L}^{-1}}$ \\
\hline & $\mathrm{ZnSO}_{4} \cdot 7 \mathrm{H}_{2} \mathrm{O}$ & $0.220 \mathrm{~g} \mathrm{~L}^{-1}$ & $10 \mathrm{ml}^{10 \mathrm{~L}^{-1}}$ \\
\hline & $\mathrm{CuSO}_{4} \cdot 7 \mathrm{H}_{2} \mathrm{O}$ & $0.079 \mathrm{~g} \mathrm{~L}^{-1}$ & $10 \mathrm{ml}_{10 \mathrm{~L}^{-1}}$ \\
\hline & $\mathrm{CaSO}_{4} \cdot 7 \mathrm{H}_{2} \mathrm{O}$ & $0.049 \mathrm{~g} \mathrm{~L}^{-1}$ & $10 \mathrm{ml} 10 \mathrm{~L}^{-1}$ \\
\hline
\end{tabular}

Preparation of inexpensive pulse bran organic culture medium

Pulse bran (Maskalai bran, Vinga mungo) was mixed with $20 \mathrm{~L}$ tap water in plastic bucket. After one week $11 \mathrm{~g}$ urea was added to each bucket. After four weeks partially decomposed pulse bran mixture was filtered through thin markin cloth and solid materials were discarded. Then after a week the supernatant was siphoned to another bucket and $2 \mathrm{~g}$ lime $(\mathrm{CaO})$ per litre of medium was mixed to make it clear and $\mathrm{pH}$ was adjusted to 7 adding $\mathrm{H}_{2} \mathrm{SO}_{4}$. Then after a week the clear supernatant was again siphoned to another bucket and this clear solution was ready as algae culture medium.

\section{Preparation of inexpensive soil extracts culture medium}

Soil extract medium was prepared according to Rahman (2011). In brief, soil was collected from bottom of a nursery pond of Field Laboratory Complex of Faculty of Fisheries, Bangladesh Agricultural University, Mymensingh. Textural class of the collected soil was "silty clay loam" which is one of the very fertile soils. After drying for 2 weeks, soil was crushed into powder to facilitate sieving. Soil was sieved through a small mesh sieve usually used to sieve rice powder for making cake. Then $2 \mathrm{~kg}$ soil was mixed with $5 \mathrm{~L}$ tap water in a plastic bucket. Soil-water mixture was kept for 5 days and during this period mixture was stirred regularly for half an hour. Then soil-water mixture was kept in this condition for several days till the settling of soil particles at the bottom of the bucket. Then supernatant was collected and sterilized in an autoclave at $121^{\circ} \mathrm{C}$ temperature and $15 \mathrm{Ib} /$ inch $^{2}$ pressure for 20 minutes. The soil extract was treated with commercial urea (5.0 g per litre) and TSP (2.5 g per litre) fertilizers.

\section{Culture of C. ellipsoidea in prepared three media}

The seeds of Chlorella ellipsoidea were collected from previous and continuous culture maintained in the laboratory of the Department of Fisheries Management, Bangladesh Agricultural University, Mymensingh. Twenty percent seeds of C. ellipsoidea were used as inoculums in $200 \mathrm{ml}$ culture medium taken in $1000 \mathrm{ml}$ conical flask. Estimations of cell density of culture of $C$. ellipsoidea collected from twelve conical flasks were done daily by a Haemacytometer following the procedure of Rahman (1992).

\section{Drying and making powder of cultured $C$. ellipsoidea}

The frozen concentrated C. ellipsoidea after thawing was dried in a microwave oven (SHARP, Japan). Then it was powdered with a mortar and pestle. Then the powder was kept in a glass tube having stopper to use as feed for rotifer.

\section{Culture of rotifers, Brachionus calyciflorus}

\section{Rotifers seed collection}

The seeds of rotifer were collected from different ponds around the Fisheries Faculty Building, Bangladesh Agricultural University, Mymensingh through selective netting with plankton nets (mesh size 55 micrometer and 250 micrometer). 


\section{Preparation of stock culture}

The seeds of rotifer were cultured in 4 plastic jars (of 5 litre capacity). Continuous aeration for 24 hrs by air pumps was arranged. Fresh cultured Chlorella was used as food for the rotifer cultured. Samplings were done regularly from each of the plastic jars for preservation (in $5 \%$ formalin) and daily analysis under a compound microscope using a special zooplankton counting cell to observe the animal and to find out culturable rotifer. At the time when the concentration of rotifer was high and the concentration of nauplii, protozoa etc. gradually decreased and finally vanished, then the whole culture was considered as stock culture.

\section{Stocking of Brachionus calyciflorus}

Brachionus calyciflorus was cultured in nine plastic jars of 3 litre capacity each containing 1 litre of water. Initial density of $B$. calyciflorus was 3 individuals $/ \mathrm{ml}$ in each jar and it was taken from the stock culture of rotifer.

\section{Feeding}

In $\mathrm{T} 1$ powdered dried $C$. ellipsoidea was given daily as feed for rotifer at the rate of $0.1 \mathrm{~g}$ per litre of water, in T2 fresh cultured C. ellipsoidea was given as $40 \mathrm{ml}$ of the concentration $2.5 \times 10^{6}$ cells $/ \mathrm{ml}$ and in $\mathrm{T} 33$ baker's yeast was given daily at the rate of $0.15 \mathrm{~g}$ per litre. Before use in the experiments, the C. ellipsoidea powder and the baker's yeast were suspended in small amount of water and homogenized by hand mixing.

\section{Aeration}

Continuous aeration for 24 hours was arranged by aerators (SIGMA 4000 SW, Japan) connected by a narrow plastic pipe and air stone on one end of the pipe to maintain an adequate supply of oxygen in every jar, during rotifer culture experiment.

\section{Estimation of B. calyciflorus densities}

Determination of Brachionus calyciflorus densities were done daily by using a special zooplankton counting cell under a compound microscope.

\section{Environmental factors}

Various environmental factors such as light intensity (lux), sunshine periods (hrs), water temperature $\left({ }^{\circ} \mathrm{C}\right)$, air temperature $\left({ }^{\circ} \mathrm{C}\right), \mathrm{pH}$, dissolved oxygen (mg L $\left.\mathrm{L}^{-1}\right)$ were estimated regularly following standard methods during the culture periods of Chlorella and rotifers.

\section{Statistical analysis}

Values are expressed as means \pm standard error of the mean (SEM). Data were analyzed by oneway analysis of variance (ANOVA) followed by Tukey's post hoc test to assess statistically significant differences among the different sampling days and different treatments. Statistical significance was set at $\mathrm{p}<0.01$. Statistical analyses were performed using SPSS Version 14.0 for Windows (SPSS Inc., Chicago, IL).

\section{Results}

\section{Environmental factors}

The results of environmental factors are shown in Table 2. Throughout the study period light intensity (lux), sunshine periods (hrs), water temperature $\left({ }^{\circ} \mathrm{C}\right)$, air temperature $\left({ }^{\circ} \mathrm{C}\right), \mathrm{pH}$, dissolved oxygen $\left(\mathrm{mg} \mathrm{L}^{-1}\right)$ were within the productive ranges and showed no abrupt changes during the experimental period in all the treatments.

Table 2. Environmental factors (Means $\pm \mathrm{SEM} ; \mathrm{n}=3$ ) during the experimental culture periods

\begin{tabular}{lccc}
\hline Parameters & \multicolumn{3}{c}{ Treatments } \\
\cline { 2 - 4 } & $\mathrm{T} 1$ & $\mathrm{~T} 2$ & $\mathrm{~T} 3$ \\
\hline Light intensity (Lux) & $3366.17 \pm 71.96$ & $3366.17 \pm 71.96$ & $3370.08 \pm 112.56$ \\
Sunshine period $(\mathrm{hrs})$ & $7.13 \pm 0.34$ & $7.13 \pm 0.34$ & $7.13 \pm 0.34$ \\
Water temperature $\left({ }^{\circ} \mathrm{C}\right)$ & $23.18 \pm 0.42$ & $23.48 \pm 0.46$ & $23.15 \pm 0.45$ \\
Air temperature $\left({ }^{\circ} \mathrm{C}\right)$ & $24.33 \pm 0.48$ & $24.41 \pm 0.43$ & $24.51 \pm 0.42$ \\
pH & $7.88 \pm 0.14$ & $7.87 \pm 0.17$ & $7.71 \pm 0.12$ \\
Dissolved oxygen $\left(\mathrm{mg} \mathrm{L}^{-1}\right)$ & $13.86 \pm 1.39$ & $13.42 \pm 1.23$ & $13.48 \pm 1.31$ \\
\hline
\end{tabular}

\section{Cell densities of the Chlorella ellipsoidea}

Cell densities ( ${\mathrm{x} 10^{6}}^{6}$ cells $\left.\mathrm{ml}^{-1}\right)$ of Chlorella ellipsoidea cultured in different media for a period of 13 days have been presented in Figures 2 and 3. The ranges of cell density of $C$. ellipsoidea were 2.345 to 10.685 ( $\times 10^{6}$ cells $\mathrm{ml}^{-1}$ ),
3.496 to $12.596\left({\mathrm{x} 10^{6}}^{6}\right.$ cells $\left.\mathrm{ml}^{-1}\right)$ and 2.765 to $11.698\left({\mathrm{x} 10^{6}}^{6}\right.$ cells $\left.\mathrm{ml}^{-1}\right)$ in $\mathrm{T} 1, \mathrm{~T} 2$ and $\mathrm{T}_{3}$, respectively. Maximum cell densities of $C$. ellipsoidea was recorded in inexpensive pulse bran extract medium (T2) during the culture period. 


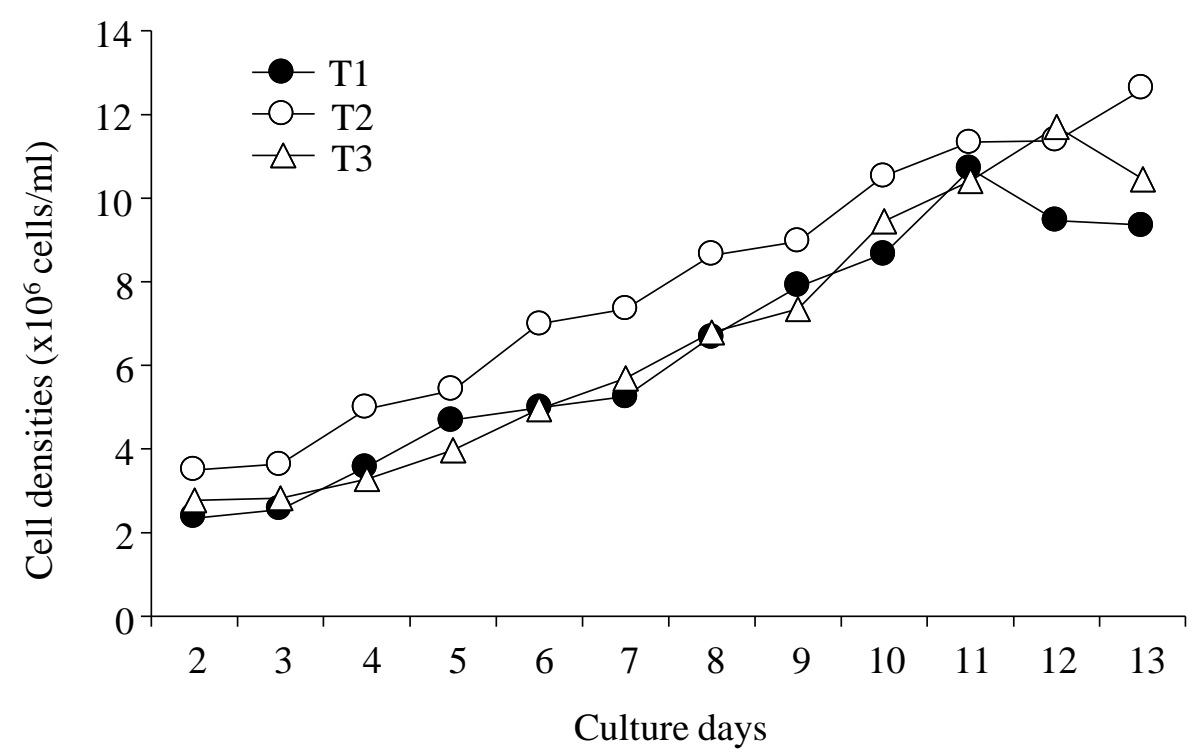

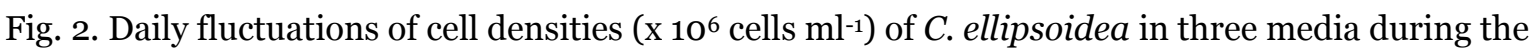
culture period of 13 days

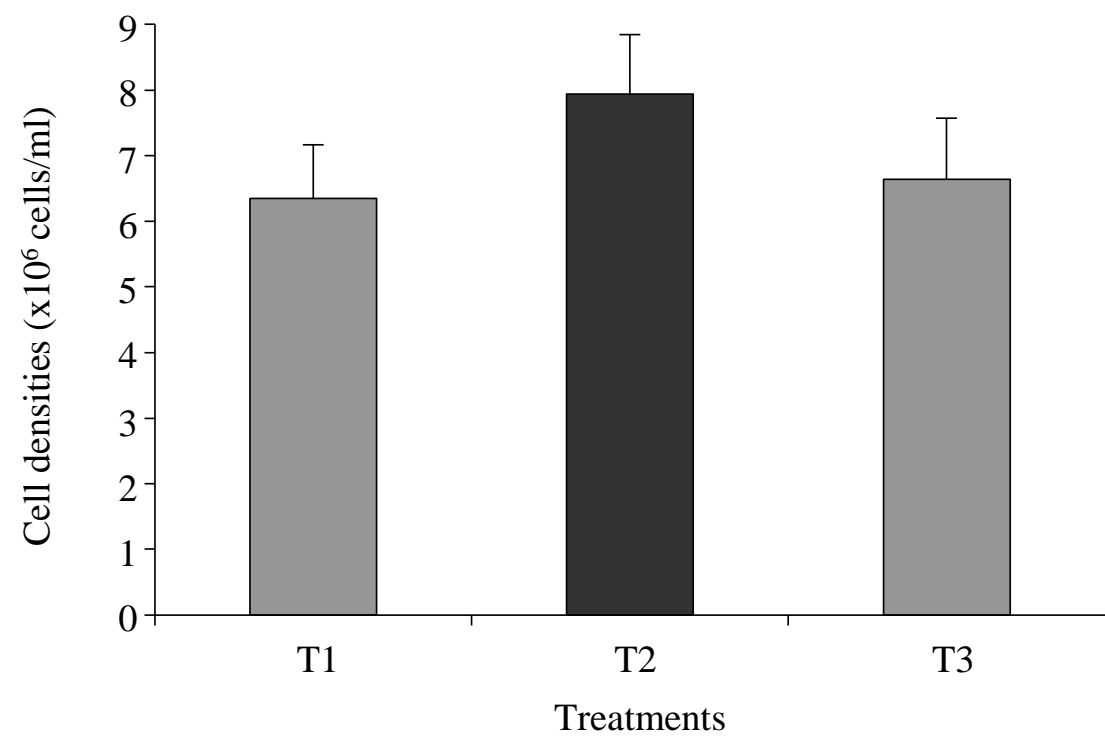

Fig. 3. Mean (Means \pm SEM) cell densities $\left(\mathrm{x}^{10^{6}}\right.$ cells $\left.\mathrm{ml}^{-1}\right)$ of C. ellipsoidea in three media during the culture period of 13 days
Population densities
$\boldsymbol{o f}$
rotifers, Brachionus calyciflorus
in $\mathrm{T} 1, \mathrm{~T} 2$ and $\mathrm{T} 3$, respectively. Mean population densities (means \pm SEM) were
Population densities (x103 individuals $\mathrm{L}^{-1}$ ) of Brachionus calyciflorus cultured in different treatment for a period of 10 days has presented in Figures 4 and 5 . The ranges of population density significantly highest $(p<0.01)$ in T2 $(28.6 \pm 4.64$ (x103) individuals $\left.\mathrm{L}^{-1}\right)$ compared to $\mathrm{T} 1(11.6 \pm 1.24$ (x103) individuals $\left.\mathrm{L}^{-1}\right)$ and $\mathrm{T}_{3}\left(11.4 \pm 1.82\left({\left.\mathrm{x} 10^{3}\right)}^{3}\right.\right.$ individuals $\mathrm{L}^{-1}$ ). of $B$. calyciflorus were 3 to 16 (x103 individuals $\mathrm{L}^{-}$ 1), 3 to 48 ( $\mathrm{x}^{1} \mathrm{O}^{3}$ individuals $\mathrm{L}^{-1}$ ) and 3 to $20\left({\mathrm{x} 10^{3}}^{3}\right.$ 


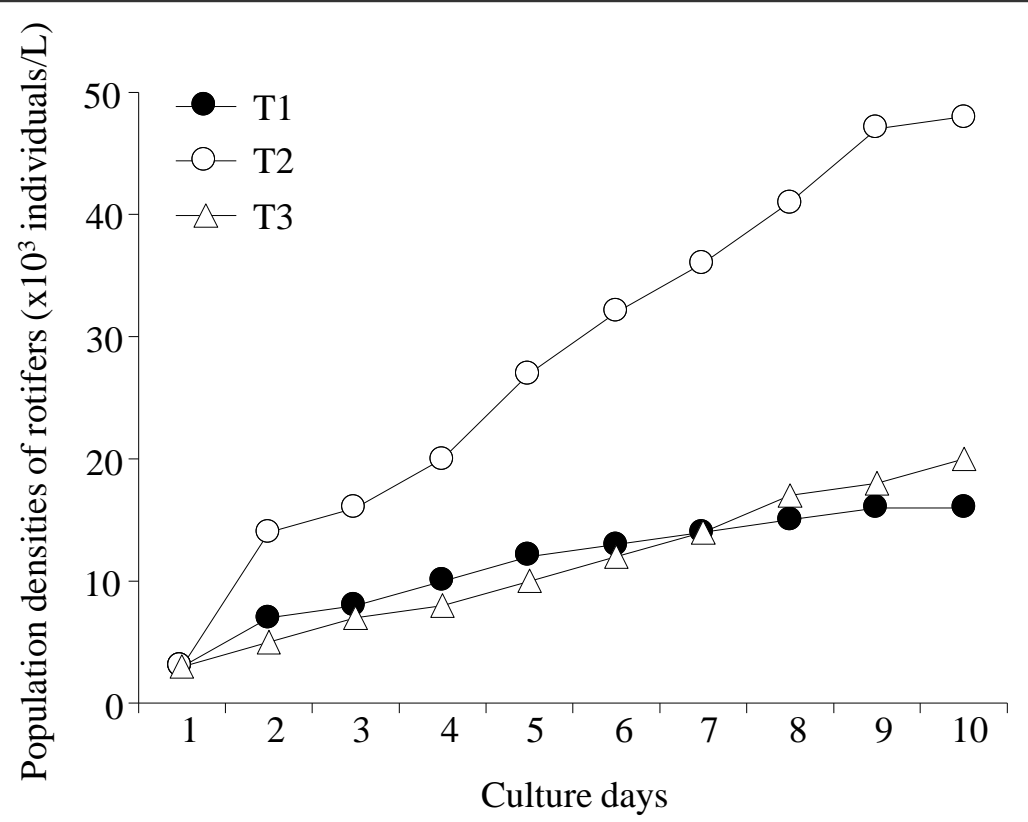

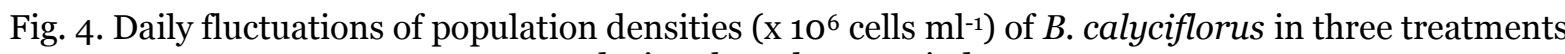
during the culture periods

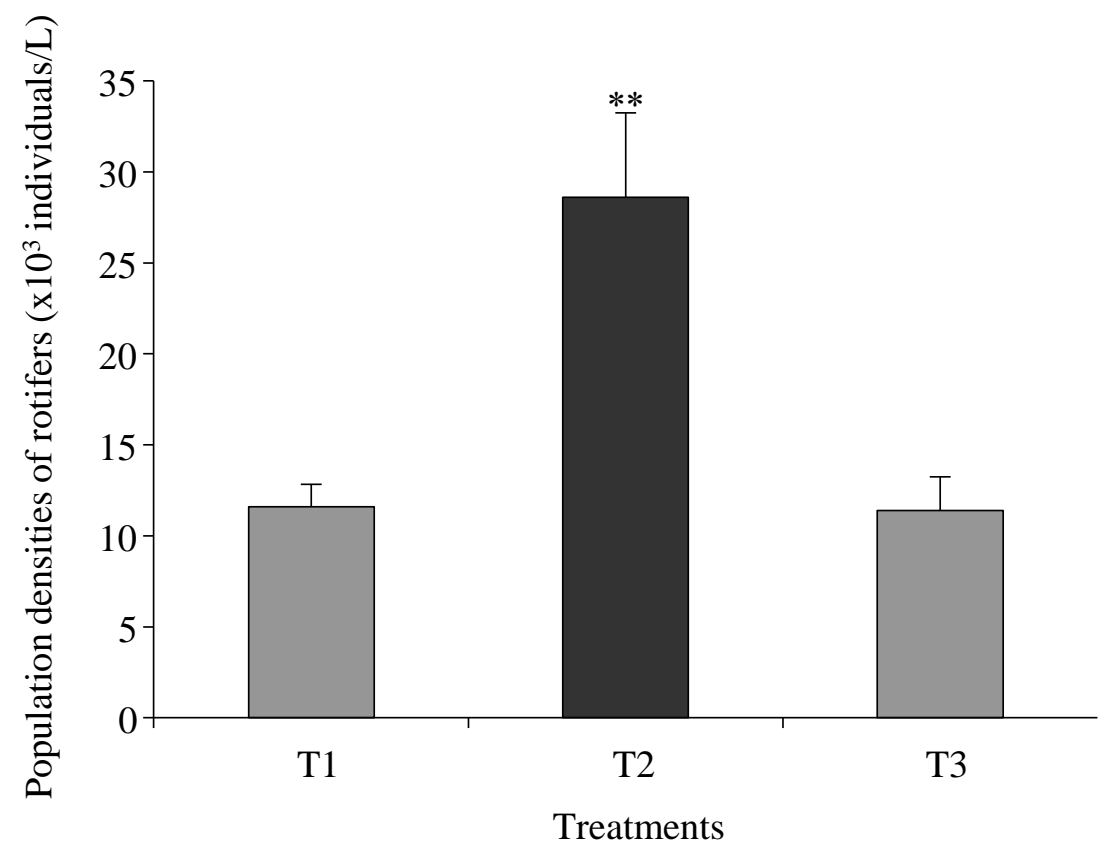

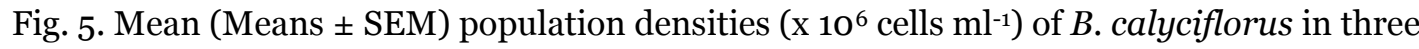
treatments during the culture periods. ${ }^{* *}$ indicated significant difference at $p<0.01$

\section{Discussion}

The present study was conducted to evaluate the suitability of Chlorella ellipsoidea as food for the rotifer Brachionus calyciflorus production. We demonstrated the highest mean population density of $B$. calyciflorus in T2 where rotifer was fed on fresh cultured live C. ellipsoidea indicated that fresh cultured live $C$. ellipsoidea is the best food for production of the rotifer, B. calyciflorus.

In the present study, the ranges of cell densities

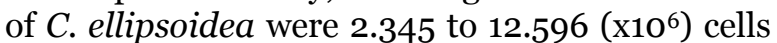
$\mathrm{ml}^{-1}$ cultured in different culture media. The maximum cell density $\left(12.596 \times 10^{6}\right.$ cells $\left.\mathrm{ml}^{-1}\right)$ was in inexpensive pulse bran extract medium on $13^{\text {th }}$ day of culture (Fig. 2). The range of cell density of $C$. ellipsoidea that found by Hossain (1996) was 0.09 to $3.63\left(\mathrm{x} \mathrm{10}^{6}\right)$ cells $\mathrm{ml}^{-1}$, which was lower than that of the present experiment. On the other hand, James et al. (1998) observed that the range of cell density was $20 \times 10^{6}$ to $80 \mathrm{x}$ $10^{6}$ cells ml-1 $^{-1}$, which was much higher than that of the present experiment. These variations of production of Chlorella might be due to culture periods, quality of culture medium and environmental conditions. 
Live algae supported the best growth of rotifers (Hirayama and Nakamura, 1976). Live Chlorella is one of the most widely used foods for culturing planktonic rotifers (Pourriot and Rougier, 1997). The mean value of $B$. calyciflorus density fed on fresh cultured Chlorella ellipsoidea under T2 of the present experiment was $28.6 \pm 4.64\left({\left.\mathrm{x} 10^{3}\right)}^{3}\right.$ individuals $\mathrm{L}^{-1}$, which is more or less similar to Awaiss et al. (1992), who reported that the production of B. calyciflorus fed on live Chlorella

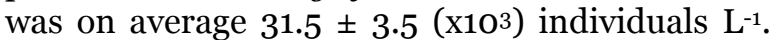
The mean population density of $B$. calyciflorus fed on powdered dried C. ellipsoidea under T1

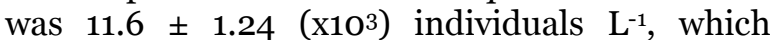
strongly agrees with Lucia et al. (2001) who found the population density of $B$. calyciflorus cultured feeding with heat-killed Chlorella ranged from $6 \pm 1$ to $26 \pm 6\left(\times 10^{3}\right)$ individuals $\mathrm{L}^{-1}$. Hirayama and Nakamura (1976) found 400 individuals $\mathrm{ml}^{-1}$ during mass culture of $B$. plicatilis feeding with dry powder of Chlorella cultured for 41 days, which is higher than that of the present study, might be due to longer days of culture period. The mean value of $B$. calyciflorus fed on baker's yeast under $\mathrm{T}_{3}$ of the present experiment was $11.4 \pm 1.82\left(\mathrm{x}^{3} \mathrm{O}^{3}\right)$ individuals $\mathrm{L}^{-1}$. Rahman et al. (1993) found that the mean values of $B$. calyciflorus fed on baker's yeast was $24.17 \pm$

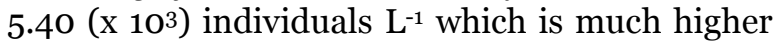
than that of the present study.

It is reflected that the mean population density of B. calyciflorus was higher under T2 where rotifer was fed on fresh cultured live C. ellipsoidea and the mean population density of $B$. calyciflorus under $\mathrm{T} 3$ where rotifer was fed with baker's yeast was lower than those of T1 and T2. This indicates that fresh cultured live $C$. ellipsoidea is the best food for the rotifer, B. calyciflorus and dried powder C. ellipsoidea is also better than baker's yeast as food for the rotifers. Although a diet of baker's yeast alone was not comparable to that of C. ellipsoidea, it can be effectively used at low concentration to supplement algal requirements in rotifer culture system (Sarma et al., 1997). It could be possible that dried and preserved $C$. ellipsoidea will be used when there is no live $C$. ellipsoidea to maintain rotifer cultures.

The environmental factors during C. ellipsoidea culture and rotifer, $B$. calyciflorus culture were found to vary within suitable ranges (Table 2). Within limit productive ranges of such water quality parameters have been observed by a number of authors (Chowdhury et al., 2008; Rahman et al., 2012; Talukdar et al., 2012; Siddika et al., 2012) for the proper growth and production of phytoplankton and zooplankton in natural conditions in the aquaculture ponds which are almost similar to those of the present study.
In conclusion, culture experiment of the rotifer, $B$. calyciflorus was done feeding with powdered dried C. ellipsoidea, fresh cultured live $C$. ellipsoidea and baker's yeast. The environmental factors during $C$. ellipsoidea culture and the rotifer, B. calyciflorus culture were found to vary within suitable ranges. The mean population densities of $B$. calyciflorus under T2 were significantly higher than those of $\mathrm{T} 1$ and $\mathrm{T} 3$. The results of present study revealed that fresh cultured live $C$. ellipsoidea is the best food for $B$. calyciflorus production and dried powdered $C$. ellipsoidea is better than baker's yeast as food for the rotifer.

\section{References}

Arimoro, F. 2007. First feeding in the African catfish Clarias anguillaris fry in tanks with the freshwater rotifer Brachionus calyciflorus cultured in a continuous feedback mechanism in comparison with a mixed zooplankton diet. J. Fish. \& Aqua. Sci. 2 (4): $275-284$.

Awaiss, A., Kestemont, P. and Micha, J.C. 1992. Nutritional suitability of the rotifer Brachionus calyciflorus Pallas for rearing freshwater fish larvae. J. Applied Icthyol. 8: 263-270.

Cheng, S., Aoki, S., Maeda, M. and Hino, A. 2004. Competition between the rotifer Brachionus rotundiformis and the ciliate Euplotes vannus fed on two different algae. Aquaculture. 241: 331-334.

Chowdhury, M.M.R., Shahjahan, M. Rahman, M. S. and Islam, M.S. 2008. Duckweed (Lemna minor) as supplementary feed in monoculture of Nile tilapia, Oreochromis niloticus. J. Fish. \& Aqua. Sci. 3: 54-59.

Dhert, P., Rombaut, G., Suantika, G. and Sorgeloos, P. 2001. Advancement of rotifer culture and manipulation techniques in Europe. Aquaculture. 200: 129-146.

Gatesoupe, F.J. 1982. Nutritional and antibacterial treatments of live food organisms: the influence on survival, growth rate and weaning success of turbot (Scophthalmus maximus). Ann. Zootech. 31: 353-368.

Groeneweg, J. and Schluter, M. 1981. Mass production of freshwater rotifers on liquid wastes II. Mass production of Brachionus rubens Ehrenberg, 1838 in the effluent of high-rate algal ponds used for the treatment of piggery waste. Aquaculture. 25: 25-33.

Hagiwara, A., Gallardo, W.G., Assavaaree, M., Kotan T. and de Araujo, A.B. 2001. Live food production in Japan: recent progress and future aspects. Aquaculture. 200: 111-127.

Hirayama, K. and Nakamura, K. 1976. Fundamental studies on the physiology of rotifers in mass culture- Dry Chlorella powder as a food for rotifers. Aquaculture. 8: 301-307. 
Hirayama, K., Maruyama, I. and Maeda, T. 1989. Nutritional effect of freshwater Chlorella on growth of the rotifer Brachionus plicatilis. Hydrobiologia. 186/187: 39-42.

Hossain, M.A. 1996. Culture of Microalgae (Scenedesmus quadricanda and Chlorella ellipsoidea) in Inexpensive Medium. MS Thesis. Department of Fisheries Management, Bangladesh Agricultural University, Mymensingh. 81 p.

James, C.M., Al-Khars, A.M. and Chorbani, P. 1998. pH Dependent Growth of Chlorella in a Continuous Culture System. J. World Aqua. Soc. 19: 27-35.

Koven, W.M., Tandler, A., Kissil, G.V., Friezlander, O. and Harel, M. 1990. The effect of dietary (n-3) polyunsaturated fatty acids on growth, survival and swim bladder development in Sparus aurata larvae. Aquaculture. 91: 131-141.

Leschenko, A., Papinachanka, T., Baran, T. and Caraba, D. 2005. The results of research in the field fish larva water belly (Coregonus albula L.) in artificial conditions. pp. 186188. In: Proceedings of the National Academy of Sciences of Belarus, Agrarian Sciences Series 5 .

Lubzens, E., Zmora, O. and Barr, Y. 2001. Biotechnology and aquaculture of rotifers. Hydrobiologia. 446/447: 337-353.

Lubzens, E. 1987. Raising rotifers for use in aquaculture. Hydrobiologia. 104: 77-84.

Lucia, P.E., Sarma, S.S.S. and Nandini, S. 2001. Effect of different densities of live and dead Chlorella vulgaris on the population growth of rotifers Brachionus calyciflorus Pallas (Rotifera). Rev. Zool. Trop. 49 (3-4): 895902.

Ludwig, G.M., Rawles, S.D. and Lochmann, S.E. 2008. Effect of rotifer enrichment on sunshine bass Morone chrysops $x M$. saxatilis larvae growth and survival and fatty acid composition. J. World Aqua. Soc. 39 (2): 158-173.

Maruyama, I. and Hirayama, K. 1993. The culture of the rotifer Brachionus plicatilis and Chlorella vulgaris containing vitamin $\mathrm{B}_{12}$ in its cells. J. World Aqua. Soc. 24 (2): 194-198.

Nhu, C.V. 2004. A Comparison of yield and quality of the rotifer (Brachionus plicatilisL. Strain) fed different diets under aquaculture conditions, Vietnam. Asian Fish. Sci. J. 17: 357-363.
Pourriot, R. and Rougier, C. 1997. Reproduction rates in relation to food concentration and temperature in three species of the genus Brachionus (Rotifera). Ann. Limnol. 33: 2331.

Rahman, M.S., Shahjahan, M., Haque, M.M. and Khan, S. 2012. Control of euglenophyte bloom and fish production enhancement using duckweed and lime. Iranian J. Fish. Sci. 11: 358-371.

Rahman, M.S., Hossain, M.K. and Habib, M.A.B. 1993. Culture of rotifer for feeding fish fry. BAU Res. Prog. 7: 676-682.

Rahman, M.S. 1992. Water Quality Management in Aquaculture. Published by BRAC Prokashana, 66 Mohakhali, Dhaka-1212, Bangladesh. pp. 71-72.

Rahman, M.S. 2011. Preparation of soil extract medium for algae culture, In "Use of soil extract as a medium for culture of Chlorella sp." MS Thesis. Department of Fisheries Management, Bangladesh Agricultural University, Mymensingh. 78 p.

Rezeq, P. and James, K. 1987. Production and nutritional quality of the rotifer Brachionus plicatilis fed marine Chlorella sp. at different cell densities. Hydrobiologia. 147: 257-261.

Sarma, S.S.S., Araiza, M.A.F. and Lopez, R.J.A. 1997. Influence of food concentration and inoculation density on the population growth of Brachionus calyciflorus Pallas (Rotifera). Env. \& Ecol. 15 (2): 435-441.

Siddika, F., Shahjahan, M. and Rahman, M.S. 2012. Abundance of plankton population densities in relation to bottom soil textural types in aquaculture ponds. Int. J. Agril. Res. Innov. \& Tech. 2 (1): 56-62.

Snell, T.W. and Carrillo, K. 1984. Body size variation among strains of the rotifer Brachionus plicatilis. Aquaculture. 37: 359367.

Stainer, R.Y., Kunisawa, R., Mandel, M. and Cohen-Bazire, G. 1971. Purification and properties of unicellular blue-green algae, (Order: Chroococcales). Bacteria Review. 35: 171-205.

Talukdar, M.Z.H., Shahjahan, M. and Rahman, M.S. 2012. Suitability of duckweed (Lemna minor) as feed for fish in polyculture system. Int. J. Agril. Res. Innov. \& Tech. 2 (1): 4246. 